\title{
Is Globalization Changing the Culture from Movie Perspectives?
}

\author{
Fang-Mei Tai', Po-Yao Chuang2 \\ ${ }^{1}$ National Penghu University of Science and Technology, Taiwan \\ ${ }^{2}$ Feng Chia University, Taiwan \\ Email: wfmtai@gmail.com
}

Received 6 September 2014; revised 21 October 2014; accepted 12 November 2014

Copyright (C) 2014 by authors and Scientific Research Publishing Inc.

This work is licensed under the Creative Commons Attribution International License (CC BY). http://creativecommons.org/licenses/by/4.0/ (c) () Open Access

\begin{abstract}
In survey of marketing, there are important issues as "Is globalization changing cultures?", "Are different cultures becoming more alike?", and "If cultures are becoming more alike, how does this affect global marketing strategies?" One of the most popular cultural practices is movie-watching; Movies and/or TV dramas are greater information sources and part of popular culture. Culture is essential to success in marketing; it is important to explore if a culture is impacted by globalization through analyzing the perspectives of movie viewers [1]. The study is designed to investigate culture using the perspectives on a film randomly chosen from 1980s Taiwan early times. First of all, the method of the study is fundamentally described through Dunning and Hofstede's theories and basic concepts of the qualitative methodologies as storytelling etc. [2]. Then, the study articulated and described the movie's story, techniques, the similarities or differences between US and Taiwanese cinema, critic on the film and praised or suggested other films, at the same time, examined and analyzed if each perspective matched the dimensions of Hofstede's Cultural theory. Finally, the analysis of the study both qualitative and quantitative provides with a significant indication of identifying the present culture in the measurement of movie perspectives, which have been the focus of mainstream strategy researchers, such as social, or reputational capital [3] and it comes into the conclusion that it is difficult and slow process for globalization changing cultures of Taiwan.
\end{abstract}

\section{Keywords}

Movie, Culture, Ideology, Globalization, Marketing Strategy

\section{Introduction}

\subsection{Globalization from Theorists}

In 1848 Marx [4] and Engels described that people would "find new wants requiring for their satisfaction the 
products of distant lands and climes" and supposed that "modern industry has established the world market" and it was called globalization today.

Dunning [5] stated that some key features of 20/21 globalization are consisting of Technological Advances, and Ideological Changes (cf. pre-1980 period): Reconfiguration of (dominating) belief systems and mindsets of several societies, and others (p. 181).

\subsection{Globalization and Tourism}

In the context of globalization, tourism industry is developing rapidly. As a result, the culture changes in tourist destinations are increasingly significant, which has become a public concern [6]. Globalization and international tourism, the latter a cause and consequence of the former, are seen to have the capacity to both threaten and help safeguard ethnic cultures [7].

\subsection{Impact of Tourism on the Original Culture}

Tourism accelerates the speed of globalization. While, the local culture is becoming less attractive gradually. However, seeking heterogeneous experience is a basic motivation of tourists; tourism destinations should maintain local characteristics [6].

\subsection{Globalization and Culture}

As globalization has become a worrisome issue for many cultures and identify/understand their cultures or cultural factors that affect consumer buying decisions will help positive achieve results in global cooperation or business competition, the study is ultimately rewarding the market success.

\subsection{Essence of Culture}

Culture has been called the way of life for an entire society. Therefore, it includes codes of manners, dress, language, religion, rituals, norms of behavior and systems of belief [8].

From Wikipedia, the free encyclopedia [9], Culture is a word for people's "way of life", meaning the way groups do things. Different groups of people may have different cultures. A culture is passed on to the next generation by learning. Culture is seen in people's writing, religion, music,clothes,cooking, and in what they do. The word "culture" is most commonly used in three ways: (1) Excellence of taste in the fine arts and humanities, as high culture; (2) An integrated pattern of human knowledge, belief, and behavior; (3) The outlook, attitudes, values, moralsgoals, and custom by a society.

The United Nations Educational, Scientific and Cultural Organization UNESCO [10] described culture as follows: "culture should be regarded as the set of distinctive spiritual, material, intellectual and emotional features of society or a social group, and that it encompasses, in addition to art and literature, lifestyles, ways of living together, value systems, traditions and beliefs" [4].

\subsection{Using Popular Movies in Cross-Cultural Management}

Popular movies, if appropriately selected and included in cross-cultural training programs for expatriate managers, immigrant workers and managers who travel to different countries, could be very useful as a tool for developing multicultural perspective and cross-cultural competence as well as a research and an instructional tool [11].

\section{Statement of the Problem}

Global markets and each country's culture are important, in order to identify how "if cultures are becoming more alike" affects global marketing strategies, the purpose of this study is to recognize whether or not globalization changes cultures, i.e., if different cultures will become more alike worldwide? As movies and/or TV dramas are richer information sources and are part of popular culture, this study is designed to recognize and analyze the culture of Taiwan by using of both interviewing the perspectives on a film and a questionnaire survey. Thus, the research questions guided the study as follows: 


\section{Purpose of the Study and Research Questions}

The purpose of this study was to do the following:

1) Measure value and concepts of the movie toward Hofstede's five Cultural Dimensions from the respondents (seniors) after taking a course "Cinema and Social Culture in Taiwan" focusing on movie culture;

2) Assess effectiveness of the instrument designed to examine (qualitative and quantitative) and verify the perspectives of various diversity of Taiwan culture described by students on Hofstede's cultural dimensions theory.

Thus, the following research questions guided the study.

RQ-1. What differences exist between the perceived Taiwan culture in a movie described by student-respondents and the perceived present Taiwan culture?

RQ-2. What is the impact of globalization on Taiwan culture?

RQ-3. How does globalization changes culture and affect global marketing strategies?

\section{Review of Related Literature}

The purpose of the literature review was to explore the existence of the culture and the research relevant studies of the factors/variables such as culture and others in a film would be as subheadings as following.

\subsection{Culture}

"Culture is a learned, shared, compelling and interrelated set of symbols and assumptions whose meanings provide a set of orientations for members of a society" [12] (p. 187). The composition of the cultural environment of international business includes language, religion, values and attitudes, law, education, politics, technology and material culture, and social organization [8].

Before dividing from Mainland China in 1949, Taiwan with China has a five thousand long/complex history and very extensive cultural resources include contemporary literature, cultural activities, local culture, the arts, religion, history, living, education, museum information, and others. In spite of many dynasties change, the culture always has patiently involved other cultures into uniformity. Consequently, people in Taiwan can find Starbucks, Nike/Barbie markets; however, the Dragon Boat Festival, the Mid-Autumn traditional festivals, Taiwan Weights, Measures \& Metric Conversions, Chinese Kung-Fu are still prevailed and used by Taiwanese and which could be said as the negative result of cultural fusion.

How "cultural capital" understood as specialized subsets of intangible resources and capabilities, enable firms to achieve valuable strategic positions in ways that are currently not explored by mainstream strategy literature [3], from which culture is a necessary factor in strategy marketing.

\subsection{Technology}

From tiny cell phones to big-screen TVs, the low weight, low power consumption, and high resolution of LCD screens, along with their low radiation levels and longevity, have made them the focus of a new generation of technology. Since 1998, LCD technology has been transferred to Taiwanese companies from Japan, and this acquired technology, together with Taiwan's own capital and talent pool, have been the main pillars of Taiwan's development of this new technology industry [13].

Taiwanese know that the only way for Taiwanese to keep the higher standard of living now is to develop technology but still to sustain Taiwan culture. That is the main target to work harder both the government and the Taiwan people.

\subsection{Recognizing Cultural Value [14]}

Measuring culture elements in movie is as an important factor in culture presentation/existence. To present current culture in the measurement of movie perspectives in Cultural domains could be: A: Cultural and Natural Heritage; B: Performance and Celebration; C: Visual Arts and Crafts; D: Books and Press; E: Audio-visual and Interactive Media; F: Design and Creative Services; Intangible Cultural Heritage (transversal domain). Related domains are: G: Tourism; H: Sports and Recreation [14]. 


\subsection{Some Key Features of $20 / 21$ Globalization}

Dunning [1] stated that some key features of globalization are (1) Market Liberalization: (a) As affecting transition economies (and (some) developing economies); (b) As affecting all economies. (2) Technological Advances: (a) Transport and communications (leading to increased speed, lower cost, improved quality); (b) Other. (3) Ideological Changes (cf. pre-1980 period): (a) Reconfiguration of (dominating) belief systems and mindsets of several societies; (b) A more intensive focus on the human (cf. the physical) environment underpinning economic activity. (4) Relative Growth of Alliance Capitalism and Network Relationships: (a) Intra firm; (b) Inter-firm; (c) Inter-organization (e.g. between governments, NGOs and firms, etc.). (5) Learning Experiences/ Trajectories of Past. (6) Emergence and Growth of New Players on World Economic Stage (especially China and India). (7) New Importance attached to the institutional Structure of Societies as a Determinant of Economic Success” (p. 181).

\subsection{Movies-Culture Ideology-Globalization}

On literature, Ideology is a key term in literary, cultural, and film studies; in 2007 Geertz [15] proposed Ideology as a Cultural System; Definition of ideology from the Merriam-Webster [16] Online Dictionary with audio is: (a) A systematic body of concepts especially about human life or culture. (b) A manner or the content of thinking characteristic of an individual, group, or culture (Merriam-Webster). Movies are part of popular culture, and culture existence could be recognized through measuring culture elements/value from movie perspectives. As mentioned above, culture is so close related with Ideology, according to Dunning, if Ideological Changes (Reconfiguration belief systems or else), which represents one of key features of globalization, then, everybody knows that globalization would be popular. Consequently, this study was designed to explore the problem of globalization by basically examining, measuring and analyzing the perspectives on the film from randomly selected respondents and a questionnaire to assess its effectiveness in Taiwan. Refer to the Figure 1, structure flowchart.

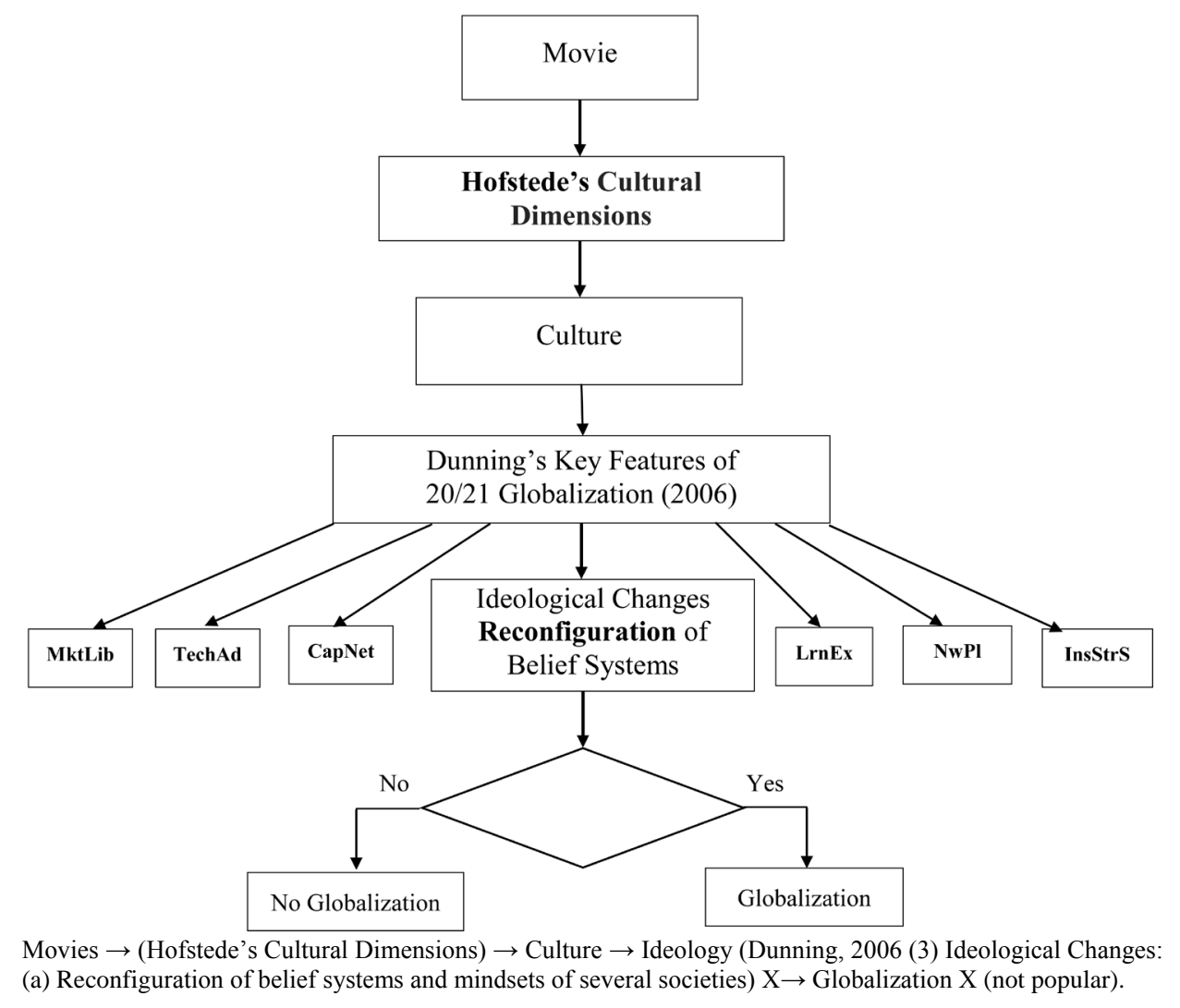

Figure 1. Structure flowchart. 


\section{Significance of the Study}

Information that emerges from the present study may:

1. Help understand whether globalization changes cultures;

2. Assist people in increasing intercultural awareness for improving international understanding and increasing positive results in global business competition.

\section{Dimensions of National Culture (vs. Cultural Dimensions and Measure Items, pp. 18-19)}

Hofstede's cultural dimensions theory. Values were measured by Hofstede's [17] original four and afterward add one more dimensions. It is a framework for cross-cultural communication, developed by Geert Hofstede. It describes the effects of a society's culture on the values of its members, and how these values relate to behavior, etc. [18].

Power distance index (PDI). "Power distance is the extent to which the less powerful members of organizations and institutions (like the family) accept and expect that power is distributed unequally". In Power Distance terms, the organization is seen as embedded with "Power Culture" where there is "relatively bounded and stable occurrences of social order based on habits of deference to authority".

Individualism (IDV) vs. Collectivism. In individualistic societies, the stress is put on personal achievements and individual rights. In contrast, in collectivist societies, individuals act predominantly as members of a lifelong and cohesive group or organization. In Individualism terms, people are interested in the work itself; thus, an organization tends to have "Achievement Culture", which assumes that people will be self-motivated and enjoy working at tasks, which are intrinsically satisfying. People also emphasize their personal commitment and achievement.

Uncertaintyavoidance index (UAI). “A society's tolerance for uncertainty and ambiguity”. It reflects the extent to which members of a society attempt to cope with anxiety by minimizing uncertainty. They try to minimize the occurrence of unknown and unusual circumstances and to proceed with careful changes step by step planning and by implementing rules, laws and regulations. In Uncertainty Avoidance terms, an organization is seen as having a "Role Culture" where people work most effectively and efficiently if they have relatively simple and clearly defined tasks. Clarity of roles and procedures fits the parts of organization together like a machine.

Masculinity (MAS) vs. Femininity. "The distribution of emotional roles between the genders". Masculine cultures' values are competitiveness, assertiveness, materialism, ambition and power, whereas feminine cultures place more value on relationships and quality of life.The Femininity Culture offers satisfaction through relationships, mutuality, belonging and connection. People contribute out of a sense of commitment to the organization. Thus it would match a "Support Culture" in organizations.

Long-term orientation (LTO) vs. Short term orientation. First called "Confucian dynamism", it describes societies' time horizon. Long-term oriented societies attach more importance to the future. In short term oriented societies, values promoted are related to the past and the present, including steadiness, respect for tradition, preservation of one's face, reciprocationand fulfilling social obligations.

Indulgence vs. Restraint (IVR). The extent to which members of a society try to control their desires and impulses.

\section{Methodology}

\subsection{Qualitative Approach}

Take the same approach of Pandey [11], this is a study based on qualitative analysis of reflection interview of three students who participated in an elective course on "Cinema and Social Culture in Taiwan" in the senior year of the BA program. The students were randomly chosen and asked to receive the interview to submit their reflection focused on classroom learning as an outcome of the course with specific reference to used movies outsourced. The reactions in the reflection provided by the students were as the survey material and which were analyzed through qualitative content analysis for this research.

The qualitative approach besides the main ways of collecting data presented above, qualitative methods can contribute to an understanding of particularly complex issues, such as habits, behaviour and attitudes, thereby improving the chance of being able to interpret the phenomena related to cultural sustainable without becoming more alike. Qualitative approaches can be properly used to investigate, in general, "why and how people choose 
to engage with the arts, their motivations for doing so and the barriers that may prevent them from engaging with the arts" [19].

Among such tools are: In depth interviews; observation, builds on literature and theories on globalization, ideology, and culture, as well as literature on related issues. This paper comprises three parts:

1. The first explorative stage based on literature review and qualitative method used.

2. The second part is based on the survey through qualitative interviewing respondents' perspectives of movie and measuring culture value from their perspectives that explores culture existence or absence of usual activities or performances along the attributes of culture in the film.

3. The third assess effectiveness of the instrument designed to verify the Dimension of Taiwan culture described by students on another researcher's theory and by a questionnaire also on Hofstede's cultural dimensions theory to implement the quantitative approach.

The objective of this paper is to examine if there is difference exist between the perceived Taiwan culture in a movie described by student-respondents and the perceived present Taiwan culture. Qualitative was conducted with 3 randomly selected senior-students using interview techniques.

\subsection{Quantitative Approach}

This study also uses quantitative to assess the qualitative approach; result almost the same.

Refer to Figure 2, methodological framework.

\section{Interview, Narrative Description, and Analysis}

As Table 1, the interview provided a unique perspective on how the plot or contents were transforming traditional approaches to the art and industry of film-making. Key indicators focus on providing a good perspective on cinema with the films - the arts (e.g. nice theme or song) and artistic and cultural activities.

Qualitative analysis is defined as the examination of non-measurable data such as a firm's reputation, a brand' image, or a customer's feelings about a product/service, e.g. movies. The following paragraphs were described narratively by one of the respondents (senior student):

(1) Cinema and Social Culture in Taiwan-the perspectives of a randomly chosen student

Talk about Taiwanese film, the great director editor and writers-Mr. Hou, H. H. would be mentioned because he is the leading figure of Taiwanese New cinema movement. One of his works is Dust in the Wind. Dust in the Wind, which is important to Taiwanese as it brings impacts to Taiwanese cinema.

(2) The Story: Dust in the Wind [20] (details refer to Figure A1)

It is about a young couple from a small village in the north-eastern part of Taiwan that experienced difficulties in life and must overcome the obstacles to survive in a big city. The boy named Ah-Yuan graduated from a junior high school, but decided not to continue any further in his education. Instead, he went to Taipei to find work so that

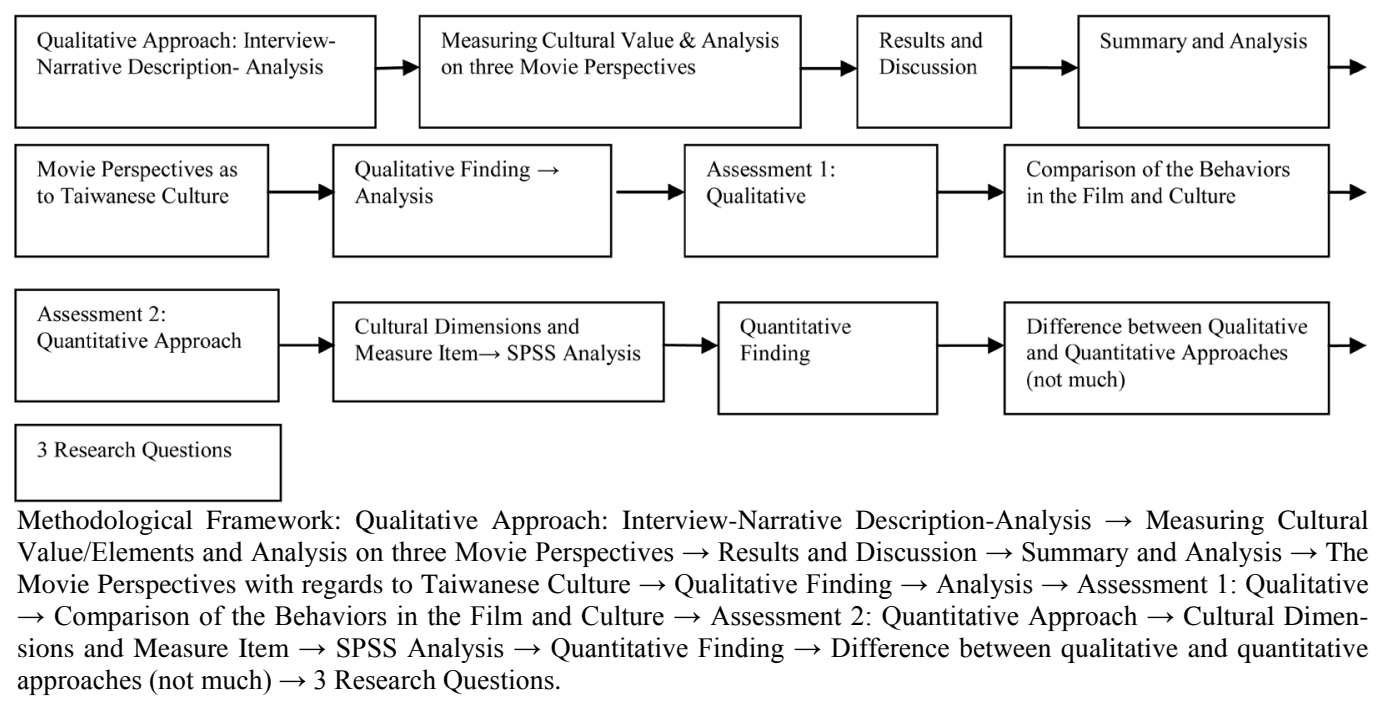

Figure 2. Methodological framework. 
Table 1. Measuring cultural value/elements and analysis on 3 movie perspectives summarized.

\begin{tabular}{|c|c|c|c|}
\hline \multicolumn{3}{|c|}{ Film Category Facts \& Differentiators } & \multirow{3}{*}{$\begin{array}{l}\text { Measuring Cultural } \\
\text { Value/Elements: } \\
\text { Hofstede's Cultural } \\
\text { Dimensions }\end{array}$} \\
\hline \multicolumn{3}{|c|}{$\begin{array}{l}\text { General Observations: All respondents offer full support for the interview. } \\
\text { All strive to provide the researcher's support at all times. }\end{array}$} & \\
\hline Perspectives + Description: Respondent 1 & Respondent 2 & Respondent 3 & \\
\hline $\begin{array}{l}\text { 1. The film was } 1986 \text { directed by Hou, } \\
\text { H. H., who is the leading figure of } \\
\text { Taiwanese New cinema movement. }\end{array}$ & $\begin{array}{l}\text { 1. Hou described realsocial } \\
\text { phenomenon-the creation } \\
\text { of focusing on living things around. }\end{array}$ & $\begin{array}{l}\text { 1. Director Hou is } \\
\text { professional at new } \\
\text { technique of filming. }\end{array}$ & \\
\hline $\begin{array}{l}\text { 2. Received Different Evaluation: } \\
\text { This movie in } 1986 \text { received } \\
\text { significant acclaim by critics. But it was } \\
\text { commercially unsuccessful. }\end{array}$ & $\begin{array}{l}\text { 2. It earned (1) The Award of Edit, } \\
\text { (2) France Nantes Film Festival: } \\
\text { - "Best Music Award” } \\
\text { - "Best Photography Award” } \\
\text { (3) Portugal Castro Oia Film Festival: } \\
\text { " Best Director Award” } \\
\text { (4) Academy Awards } \\
\text { - "Best Director Award” }\end{array}$ & $\begin{array}{l}\text { 2. The film's popularity } \\
\text { reaches worldwide. }\end{array}$ & $\begin{array}{l}\text { 2. Power Distance } \\
\text { Index (PDI) } \\
\text { (Awards) }\end{array}$ \\
\hline
\end{tabular}

\section{Movie Technique:}

(1) - (3) Uncertainly

(1) Lighting: There weren't many lighting techniques used in Dust in the Wind; they mostly use natural lighting throughout the film.
(1) Emphasis on personal experiences and memories of growing.
(2) Created Techniques: Hou created his own types for this film -Minimal amount of dialogues, no movement and expression, beautiful wide angle shots, no close-up, no follow shot, no panning, and no whip pan. Anyway, some of his techniques are still being used in Taiwanese films today.

\section{(3) New Actors/Actress used \& Not in Studios:} It was filmed in local areas with actors and actresses that had no experience or training in acting; moreover, every scene was not filmed in studios and had no special fast-paced editing, which means that the scenes usually is quite long.
(2) The film seems to closer to the role of the man in the street to construct the general public living experience, express concern Taiwanese culture. That's great.

(3) Since our eyes don't move as fast as the camera fast-pasting angel, so it's better for the audience to see the whole long shot in the film and clear the culture more.
Avoidance (Trials)

(1) With deep focus on photography and emphasis long lens aesthetics, with a realism and modernism style.

(2) There were strong local nature, close to the Taiwanese people's lives:

Use of local resources.

(3) It's very nature, not artificial for actors/actress with no experience which works perfectly in the film.

(1) It was made by Phase a spectrum with human interaction poems, very good. accompanied with the friendship in the mountain, rhythm of forest conversations or dialogue in the entire movie. There was a scene where Ah-Yun sent Ah-Yuan off at the train station, but did not talk the entire time while waiting for the train to come; they both kept silent even until they had parted ways.

(2) Encourage Context: I could understand that they were experiencing many difficult situations in life, but why would Mr. Hou not include some basic dialogue in this film? As I guessed, Mr. Hou did this on purpose because he wanted the audience to think about the context of the film.

\section{(3) Cinematography \& Content different:}

The comparison does not match up at the first place because we did not compare films that are in the same genre. Obviously, the more notable and successful Hollywood films are lots of action, fighting, special effects, and fast paced cuts. Shawshank Redemption (1994), The Godfather (1972) are ranked in the top movies of all time and use little no to no special effects, fast cuts, or intense action in their movies.
(2) I like that kind was into the world of imagination even converted to think about life's attitude reflected by the screen.

(3) Comparison is when you compare different objects that are similar to each other.

I still think Taiwanese films full of culture are better to watch.
(1) Uncertainly

Avoidance (Audio-Visual)
(2) It was an understandable movie for audience to not a lot of details in the film.

(3) The main reason those old Hollywood cinema became successful is because it's entertaining and fun to watch. clear even there was
(2) Uncertainly

Avoidance (Effects-Spirit) Avoidance (Customer Service)

\section{(3) Uncertainly}




\section{Continued}

\begin{tabular}{|c|c|c|c|}
\hline $\begin{array}{l}\text { (4) Similar toThe Breakfast Club except entertaining } \\
\text { and great story: made in 1985, around the same time } \\
\text { of Dust in the Wind in the late 1980's. None of those } \\
\text { actors or actresses was professionally trained; } \\
\text { also the entire movie was filmed in the local areas. } \\
\text { Critics considered as one of the greatest high }\end{array}$ & $\begin{array}{l}\text { (4) But I think, it has a dull realistic } \\
\text { life with concatenated into family life, } \\
\text { youth or a living wage, sometimes just } \\
\text { like a documentary film. Valuable! }\end{array}$ & $\begin{array}{l}\text { (4) If studio records } \\
\text { the film with realistic } \\
\text { life and not much of } \\
\text { dialogues, but I think } \\
\text { that is one of purposes } \\
\text { for this film. }\end{array}$ & $\begin{array}{l}\text { (4)Uncertainly } \\
\text { Avoidance } \\
\text { (Customer Service) } \\
\text { Or } \\
\text { Collectivism } \\
\text { (Family Theme) }\end{array}$ \\
\hline
\end{tabular}

school/coming-of-age films of all time.

While, it has comedy and entertaining,

and it is mainly because it has a great story line,

I think; Dust in the Wind has no a great story.

5. More Context than Content: possibly makes viewing the film into the wrong way or in an unintentional way:

\section{(1) His Bride Married To Another Guy:}

One possibly unintentional observation may be that

Ah-Yun is a faithless woman who cheated on

Ah-Yuan without telling him about her marriage

to a good job-postman officer until three years later.

\section{(2) Less Confidence:}

Another possible observation is that

Ah-Yuan is a loser, who can't handle a simple job tasks and is too scared to speak up to Ah-Yun anything.

\section{(3) Until Very Adult:}

Ah-Yuan's father pours the wine for Ah-Yuan is to show his father finally treats him as a man instead of little boy. But if Ah-Yuan's father gave him a persuasive speech instead that way, the audience would think his father is an influential person.

(4) Lack Courage to Express One's Own Feeling: Even though they were living closer to each other, their relationship was strained from their inability to express the love that they have for one another.
(1) Ah-Yun may thought there is no future between her and

Ah-Yuan so decided to take further steps for her life.

(2) Ah-Yuan only care about himself which makes him a selfish person.

(3) Trustworthiness Tolerance, Moral, Intimate character: Ah-Yuan's mother showed symbol of trust worthiness and still hoped to give the ring (his family's Heirloom) to Ah-Yun, even though she was married to other man; the grandfather's tolerance, moral, intimate young.

character, are all the traditional of Chinese human generations.

(4) Ah-Yuan needs to be more confidence about himself. However, that is kind of human.

\section{The Audiences:}

Mr. Hou's films would be interesting to the older generation of viewers nostalgia or those who enjoy absolute realism.

(1) It's surprising to see Ah-Yun married to a post man at the end.

(2) Ah-Yuan had not enough self-confidence to speak even for his job tasks.

(3) For Chinese traditional loyalty, the two families didn't want to break as the agreement was made early when the couple were very

(4) The Relationship of the couple involved several challenges but Ah-Yuan didn't face any of those. Maybe he was younger with a little impetuous.

Everyone has different Power Distance

I like the film, a new generation of viewers like it, too; and it also would meet foreigners to look at these films as Taiwan growth history. taste in watching films. Index

(Service) +

\section{Entertainment and Great Story is the Key to Attract the Audience}

Cape No. 7 and You Are the Apple of My Eyes are the more successful Taiwanese films for audiences even internationally to watch. In the beginning there are some films may be considered low budget or bad "quality", at last they receive loved and their true quality generally lies within the storytelling.

\section{The Ways the Film as a Significant indication of the Social Culture Taiwan}

(1) Military Service:

a. Males aged 18: adult males need to participate into the military at the age of 18 ;
Story is important, Taiwan is full of story resource.
But I like the films analyzing real social phenomenon.
Uncertainly Avoidance
(1)Uncertainty

Avoidance

(Ah-Yun's faithless)

(2) Uncertainty

(3):High Levels of Collectivism (Family) culinity (Ah-Yuan)
(1)

a. Taiwan was in war with China during 1949-1987.
(1)

a. Even in the modern day, military Taiwan still drifts the middle-aged males to military sometimes.

b. Ah-Yun should have b. Power Distance showed up when she (Ah-Yun married to a was about to marry to powerful man with the other person.
(1)

a. Collectivism

(Military) b. Affect Young Couple's Marriage:

b. Ah-Yun discovered the post man has Young ladies do not want to wait for the men to completestable income and decided to marry him their service that influencing to marry to another gay; 


\title{
Continued
}

c. Regulatory Reform Towards Evening: Taiwan $\quad$ c. Taiwan's policy is not as strictly as changes in rules and policies of military requirement or before nowadays. laws often. The actor Ah-Yuan was drafted to military under age of eighteen, earlier than required.

\author{
c. The timing is strange c. Uncertainty \\ for audience to Avoidance \\ understand why all of (often changes in \\ the sudden Ah-Yuan rules/policy) \\ was forced into army \\ (due to possible policy \\ changes). \\ (2)

\section{a. Females are} \\ considered as \\ housewives in the \\ Chinese traditional \\ family while the males (Males are important) \\ go out to work. \\ b. Males are more \\ valued in Chinese \\ traditional culture.
}

(2)

(2) Gender Issue:

Taiwanese people still have a really strong traditional sense, such as men being more dominate than women a. Females Should Listen to Males: Ah-Yuan was ma about Ah-Yun's drinking alcohol with several men in the dinner table- this scene indicates a kind of dominate control, where the male believe the female should follow his orders. Gender still impacts today's Taiwanese society.

b. Bias against Females: Elders and parents treat their sons and daughters in a different way. a. Not only Gender issue, but the younger to respect elders were raised in this film, too. Males are considered more important than female because male carries family's name.

9.Emotional Challenge: One aspect of the film that does not quite match up with modern Taiwanese social culture is the communication:

(1) Throughout the entire movie both of them never confess or talk to each other; (2) If you're in love with someone, you should have some indication of passion, infatuation or even actions to show your love; (3) This is not the way the director chose to have the characters express their feelings
10. What I learn from the film on culture, anyway? I appreciate the Director taking good photographing by beautiful wide angle shot, etc., and others so that the thing or activities in 1980's could be seen and understood. And real record of social life and history of Taiwan, let people tell the story directly in the lens, and focus on Life. Thanks.
(1) The young couple were lack of communication.

(2) The director wanted the audience to think what was going to this couple. Instead of dialogues, director gave the audience foreshadowing in the film. (3) Director wanted to have a different specific express and feelings in the film.
(1) Strength of the film should be focus the life.

(2) Director Ho produced plain, very simple, all people can see, and he did record of the past and the present, Taiwan. I am grateful to him; and made me have three philosophical attitudes to life: after deep experience, to love nature/life, respect,

\begin{abstract}
(1) It is a plain film.

(2) Since there is no great plot and story in the film, it's obviously there is not much of complicated relationship in the film in earlier times of Taiwan. (3) Director wants to test out new techniques of film.
\end{abstract}

(1)-(3). Uncertainly storytelling with the Avoidance and beautiful scenes in the Power Distance

Good Director! (Conservative
before, gradually
tends to the indication
of passion, infatuation
or even actions to
show your love.) understanding, and tolerance.

he could start earning money. The girl he loves, Ah-Yun, followed him the next year and found a work in Taipei to save up money, in hopes that they would have enough to get married. Even though they were living closer to each other, their relationship was strained from their inability to express the love that they have for one another. Unfortunately, Ah-Yuan was suddenly drafted to the military for three years. Ah-Yun had waited for him, but could not wait any longer after a couple years. Ultimately, she decided to marry a postman without her family approval.

(3) How the Film relevant to the observations or experiences in Taiwan on the Movie Technique

This movie was released in 1986 and received significant acclaim by critics. However it was commercially unsuccessful. It was filmed in local areas with actors and actresses that had no experience or training in acting; moreover, every scene was not filmed in studios and had no special fast-paced editing, which means that the scenes usually is quite long. Why it became significantly acclaimed by New Taiwanese Cinema? I think it was because Mr. Hou wanted to try out different filmmaking techniques by not following the usual cinematography techniques of the time. Instead, he created his own types of techniques for this movie: Minimal amount of dialogues, no movement and expression, beautiful wide angle shots, no close-up, no follow shot, no panning, and no whip pan. Some of his techniques are still being used in Taiwanese films today. Also, I realize 
there weren't many lighting techniques used in Dust in the Wind; they mostly use natural lighting throughout the film. It is easy to see why Mr. Hou's projects became widely known in Taiwan.

(4) The difference between US (Hollywood) and New Taiwan Cinema

Personally I think that Dust in the Wind is an unusual movie; it may be due to the fact that I have not seen old Taiwanese movies like it. I often found myself lost and confused in some parts of the film when I first saw it. The protagonists, Ah-Yuan and Ah-Yun, do not have many conversations or dialogue in the entire movie. For instance, there is a scene where Ah-Yun sends Ah-Yuan off at the train station, but did not talk the entire time while waiting for the train to come; they both kept silent even until they had parted ways. I could understand that they were experiencing many difficult situations in life, but why would Mr. Hou not include some basic dialogue in this film? As I guessed, Mr. Hou did this on purpose because he wanted the audience to think about the context of the film. Let's compare Hollywood cinema's and New Taiwan cinema's difference with the basis of filmmaking, which includes cinematography and content. In my opinion, the comparison does not match up at the first place because we did not compare films that are in the same genre. I am comparing Dust in the Wind, made in 1986, with Avengers or Iron Man, which only came out recently in the 2008-2012. Obviously the more notable and successful Hollywood films are the ones with lots of action, fighting, special effects, and fast paced cuts. However, there are other many well known and equally successful dramatic movies that have received much acclaim from critics worldwide. For example, dramatic movies like Citizen Kane (1941), Shawshank Redemption (1994), The Godfather (1972) are ranked in the top movies of all time and use little no to no special effects, fast cuts, or intense action in their movies. Another movie that is comparable Dust in the Wind is The Breakfast Club, made in 1985, around the same time in the late 1980's. The Breakfast Club has been a famous film in America for a long time; its fame even reached globally. It is both critically acclaimed and financially successful due to its popularity and connection to its audience. None of those actors or actresses was professionally trained; also the entire movie was filmed in the local areas. Critics considered The Breakfast Club as one of the greatest high school/coming-of-age films of all time. Is it because it has comedy and is entertaining? I would say both but it is mainly because it has a great story line.

\section{(5) More Context than Content in Mr. Hou's Movie}

Compared to Dust in the Wind, Mr. Hou wanted the audience to think about the context of the film rather than the content; however, without some specific content the audience may end up receiving the message or viewing the film the wrong way or in an unintentional way. One possibly unintentional observation may be that Ah-Yun is a cruel woman who cheated on Ah-Yuan without telling him until three years later about her re-marriage, while he was still in the military. Another possible observation is that Ah-Yuan is a loser, who can't handle a simple job tasks and is too scared to speak up to Ah-Yun. There are a few foreshadowing and hints to tell the audience about the couple but I think those aren't necessary to be in the film. For instance: Ah-Yuan' father pours the wine to Ah-Yuan to show his father who finally treats him as a man instead of little boy, this techniques were used in many other old films too. It would be better if Ah-Yuan's father give him a persuasive speech instead, that way the audience would think his father is an influential person.

(6) Other Films for Audiences even Internationally to Watch

From my observation, I can see that Taiwanese Cinema is trying to catch up to the filming techniques as the American Cinema. Mr. Hou's films may be interesting for older audiences or those who enjoy absolute realism, but is not too interesting for the general audience. There are many new filmmaking techniques that can capture the same emotions or feeling of dramatic situations like in this film even better if used correctly. 海角七號 (Cape No. 7) and 那些年, 我們一起追的女孩 (You Are the Apple of My Eyes) are the more successful Taiwanese films for audiences even internationally to watch. Entertainment and good story is the key to attract the audience. There are many successful and widely acclaimed movies that in the beginning may be considered low budget or bad "quality" compared to the bigger "Hollywood" types; however, at last they receive loved and their true quality lies within the storytelling.

(7) The ways I consider it as a significant indication of knowing the social culture in Taiwan

My observation on Dust in the Wind is that some similarities and differences to the Taiwanese culture today. Taiwan's new military system has reduced the amount of years to a couple months in military but still require adult male to participate. In situations like being a continuing graduate students, they are required to enlist in the military after graduation. Some Taiwanese women do not want to wait for men to complete their service in military. I think it is because that when the men complete their service in military; they won't able to find a proper job right away, which is the reason influenced Ah-Yun married to another well-paid average gentleman in the movie. I 
figured that Ah-Yuan was drafted to military under age of eighteen (maybe 16), which didn’t make sense in the movie as generally the age requirement to join the military in Taiwan is at least eighteen years old. Ah-Yuan started to work around age of sixteen then received a military letter just a year later-unreasonable! It is most likely due to changes in rules and policies from military requirement and laws often.

In addition, Taiwanese people still have a really strong traditional sense, such as men being more dominate than women. In the movie, Ah-Yuan was mad about Ah-Yun drinking alcohol with several men in the dinner table; this scene indicates a bit dominate control, where the male believe the female should follow his orders. Gender still impacts today's Taiwanese society, especially elders and parents treat their sons and daughters in a different way. One aspect of the film that does not quite match up with modern Taiwanese social culture is the communication. In the film, it is only implied that Ah-Yuan and Ah-Yun are in love with each other, but throughout the entire movie both of them never confess or talk to each other. If you're in love with someone, you should have some indication of passion, infatuation or even actions to show your love, especially for young people. However, this is not the way the director chose to have the characters express their feelings”.

\section{Results and Discussion}

Enjoy movies as learning experience and awaring culture. Pandey [11] proposed popular movies, appropriately selected, could as a research or an tool for exploring the culture or psychodynamics of learning in management and social sciences courses or professional training programs focused on cross-cultural management skills, global leadership skills; i.e., it is very useful as a tool for developing multicultural perspective and cross cultural competence.

In 2006 Dunning, it is only when Ideological Changes specially in Reconfiguration of (dominating) belief systems and mindsets of several societies as well as ....activity and others, then, globalization comes. From the above, we understand the three respondents' perspectives generally were satisfied with this film even it was taken in earlier times so we don't see Taiwan needs any reconfiguration of belief system or mindsets of several societies nor anything needed to change even though the survey samples are not much; therefore, Taiwan culture should still be existed in most Taiwanese way of life, the times of vigorous globalization is a long way to come to our side. The research has found and implications as the following Table 2.

\section{Qualitative Finding}

Hofstede's cultural dimensions theory describes the effects of a society's culture on the values of its members, and how these values relate to behavior.

Table 2. Summary and analysis: the movie perspectives with regards to Taiwanese culture.

\begin{tabular}{|c|c|}
\hline Critical Film Elements & Dimension of Taiwanese Culture (By Hofstede’s National Culture) \\
\hline Overall Performance & $\begin{array}{l}\text {-Power Distance: the less powerful members of the group expect and accept that power is distributed unequally; } \\
\text { emphasis on differentiation-the awards granted to the edit, music, Director, photography, and significant } \\
\text { acclaim by critics but commercially unsuccessful. }\end{array}$ \\
\hline $\begin{array}{l}\text { For the Audience } \\
\text { (Spirit of Work) }\end{array}$ & $\begin{array}{l}\text {-Uncertainty Avoidance: adventurousness, eager to take new chance, less care about risk- the techniques by } \\
\text { using-natural lighting, the Director's own types, new actor/actress, not filmed in studios, make audience to think } \\
\text { about the context, different cinematography \&Content, less entertaining nor great story in this film. }\end{array}$ \\
\hline $\begin{array}{l}\text { Times-Theme Selection } \\
\text { \& Processing }\end{array}$ & $\begin{array}{l}\text {-Uncertainty Avoidance (Ah-Yun's faithless) \& Power Distance (Married to powerful man) } \\
\text {-Uncertainty Avoidance(Less confidence to face problem of job tasks, etc.) } \\
\text {-Collectivism with high level (Family's moral, tolerance, etc. are traditional virtues) } \\
\text {-Masculinity low level (Ah-Yuan worked to receive personal rewards worth the effort spent) }\end{array}$ \\
\hline $\begin{array}{l}\text { The Ways as a Significant } \\
\text { Indication of Social Culture }\end{array}$ & $\begin{array}{l}\text {-Collectivism (Military Service: Males aged 18) } \\
\text {-Power Distance (Military Service affects young couple's marriage) } \\
\text {-Uncertainty Avoidance (Military Service often changes in rules/policies) } \\
\text {-Masculinity (Females should listen to Males) } \\
\text {-Masculinity with high level (Bias Against Females: Males are more important by the elder or parents) } \\
\text {-Uncertainly Avoidance \& Power Distance (Conservative before, gradually tends to change into the indication of } \\
\text { passion, infatuation or even actions to show your love) }\end{array}$ \\
\hline
\end{tabular}

Power Distance Index (PDI): 4 (cases); Uncertainty Avoidance Index (UAI): 5 (cases); Individualism (IDV) vs. Collectivism: 0/2 (cases); Masculinity (MAS) vs. Femininity: 3 (cases); Long-term Orientation (LTO) vs. Short term Orientation: 0 (cases); (UAI > PDI > MAS > IND/COL). 


\subsection{Analysis and Result}

1) Of the dimension of Taiwanese culture in this film, Uncertainty Avoidance Index (UAI) was described or perceived by respondents and analyzed as the most popularly used to relate the behaviors to Taiwanese culture value, UAI = 5 Cases; and Power Distance Index, PDI $=\mathbf{4}$ Cases, is the next.

2) While Individualism (IDV = 0), and Long-termor Short-term Orientation (LTO = 0, STO $=0$ ) were considered by respondents as their least used to reflect the behaviors or perception to Taiwanese culture in this film.

3) Collectivism is second to the last used to relate Taiwanese behaviors to culture (Collectivism $=2$ ) in this film.

4) The dimension of Masculinity, MAS = 3 Cases, in this film were a moderately used dimension.

5) All of the behaviors described from the beginning to the end in the film were all related to Taiwanese culture dimensions without any exception.

6) The film earned awards of three international and one Taiwan domestic on edit, music, Director, photography, the older/new generation of viewers as well as the foreigners (e.g., France, Portugal) like it.

\subsection{Analysis}

1. Uncertainty Avoidance: It is a society's tolerance for uncertainty and ambiguity. Historical experience of Chinese for thousands of years of wars, Chinese people in the culture naturally tend to be more less care about risk, they are more tolerant of adventurousness, and eager to take new chance. Therefore, the techniques used by this film, i.e., natural lighting (more natural), the Director's own types, new actor/actress (none was professionally trained), not filmed in studios, make audience to think about the context, different cinematography \& Content, less entertaining nor great story, still won five awards international and domestic. The techniques in this film matched the culture dimension of uncertainty avoidance with considerable levels of success. However,

The couple did not have good ending; Ah-Yun's faithlessness to Ah-Yuan (low Uncertainty) so she chose to marry to another man having more stable (powerful) job. Ah-Yuan's silent personality made not much dialogues or communications with Ah-Yun (instead of passion, even actions to show his love) or was not confidence enough to face his job tasks, etc were all the examples of low Uncertainty. However, the film was choosing not to avoid or deny these non-perfect characters but honestly truly present the life (the culture) to the audience.

Taiwan's Military Service has been changed in its rules or policies. Before males went to the army at the age of eighteen, were not allowed to go abroad, and were very serious in the training; but it is now significantly different, service time is shortened and not so harsh or rigid, which also belongs to Uncertainty Avoidance. UAI has five Cases in this film, Uncertaintyavoidance is highly involved in Taiwanese's life or way of life or culture is identified.

2. Individualism: Individualism is more emphasized by young people who expect to stand up for themselves; however, people have large extended families, which are used as a protection in exchange for unquestioning loyalty. In collectivist societies, individuals act mainly as members of a lifelong and cohesive group or organization. At first Ah-Yuan went to Taipei to pursuit quality individual life; thereafter, through the time of military service (collectivism), and further his knowing Ah-Yun became other's bride, he returned his hometown, which could be as a protection for his unquestioning loyalty. Chinese people are tending to low Individualism [17]; therefore, Individualism—zero case and Collectivism 2 cases_-second to the last in this film are reasonable.

3. Power Distance: In 2001, Hofstede stated, Chinese naturally belong to high power distance. Cultures that endorse low power distance expect and accept power relations that are more consultative or democratic. People in these cultures tend to be more pragmatic, they are more tolerant of change. In this film there are 4 cases of Power Distance:

(1) As less powerful members of the group expect and accept that power is distributed unequally and prefer fix work in one professional field with the related powers emphasis on autonomy, differentiation; therefore, this film won many awards of edit, music, Director, photography, and significant acclaim by critics even though commercially unsuccessful.

(2) Subordinates tolerate inspection and distribution of power at work, Military Service affects young males' life, life direction, even young couple's marriage; Ah-Yun may thought there was no future between her and Ah-Yuan so decided to take further steps for her life, not married to Ah-Yuan but a stable (powerful) man. She was impacted and wanted to have mutual support of Power Distance. 
4. Masculinity\& Femininity: In Dimensions of Cultural Values of Hofstede [14], Masculinity describes a society: Men are supposed to be assertive, tough and focused on material success; whereas women are supposed to be more modest, tender, and concerned with the quality of life (p. 262). The Femininity Culture offers satisfaction through relationships, mutuality, belonging and connection. In this film there are three cases of Masculinity which were moderate, not high nor low. In the film,

(1) Ah-Yuan lacks encourage to express his love to Ah-Yun, who grew up with him together since childhoodlow Masculinity; however,

(2) Ah-Yuan was mad about Ah-Yun's drinking alcohol with several men in the dinner table, which indicated that Females should listen to Males' order; and

(3) It is bias concept: Males are more important than females by the elders or parents even the times of today. Generally, Taiwanese had had with a high MF scores and tended to reflect a more masculine assertiveness, aggressive, calculative, advancement type attitude, whereas, it is now getting trend to reflect a feminine type of cooperative or modesty behavior, and which is consistent with the result of this study in moderate degree of Masculinity.

5. Long-Term/Short-Term Orientation is the extent of which individuals think and behave for future rewards or present values [21], had not found by the respondents in this film.

6. The film earned three international and one Taiwan domestic awards on edit, music, photography et., the older and new generation of viewers (even if a little critic) as well as the foreigners all like it, which represents Taiwanese culture's existence and characteristics through the movie. That is, Taiwan culture is not integrated into other culture or is not becoming more alike, globalization is not changing Taiwan culture so fast.

\section{Assessment 1: Qualitative}

Assess the effectiveness of the instrument was designed to verify and relate the Taiwanese behaviors (described by students) to the Dimension of Taiwan culture on Wikipedia's Concept of Culture as follows:

“Culture is a word for people's 'way of life', meaning 'the way groups do things'. Culture is seen in people's writing, religion, music, clothes, cooking, and in what they do.

According to the conceptof culture, culture is most commonly used in three ways as Table 3.

1. Excellence of taste in the fine arts and humanities, known as high culture.

2. An integrated pattern of human knowledge, belief, and behavior.

3. The outlook, attitudes, values, moralsgoals, and customs shared by a society”.

From the Comparison Table 3, we can see the corresponding of the Behaviors with the Culture, that means, the Behaviors match Wikipedia's Concept of Culture, we come to understand Taiwanese culture through movies, so do our younger generation even if they watched the film after twenty-eight years since the film was made.

Table 3. Comparison of the behaviors in the film and culture.

\begin{tabular}{|c|c|c|}
\hline The behaviors (Elements) of the Film & Wikipedia's Culture & Match \\
\hline $\begin{array}{l}\text { Overall Performance: } \\
\text { The film earned awards of edit, music, Director, photography. }\end{array}$ & 1. Excellence of taste in the fine arts and humanities. & Yes \\
\hline \multicolumn{3}{|l|}{ For the Audience: } \\
\hline $\begin{array}{l}\text { The techniques of the film by using: } \\
\text { natural lighting, the Director's own types, new actor/actress, not filmed in } \\
\text { studios, make audience to think about the context, different } \\
\text { cinematography \& Content, less entertaining nor great story in this film. }\end{array}$ & $\begin{array}{l}\text { 2. An integrated pattern of human knowledge, } \\
\text { belief, and behavior. }\end{array}$ & Yes \\
\hline \multicolumn{3}{|l|}{ Theme Selection \& Processing: } \\
\hline $\begin{array}{l}\text { Ah-Yun's faithless, mrried to a more powerful man, } \\
\text { The actor's less confident to face job tasks, etc. } \\
\text { Family’s moral, tolerance, etc. are traditional virtues, } \\
\text { Ah-Yuan working to receive personal rewards worth the effort spent. }\end{array}$ & $\begin{array}{l}\text { 3. The outlook, attitudes, values, moralsgoals, } \\
\text { and customs shared by a society. }\end{array}$ & Yes \\
\hline The Ways as a Significant Indication of SocialCulture in Taiwan: & & \\
\hline $\begin{array}{l}\text { Military Service: Males aged 18, } \\
\text { Military Service Affects Young Couple’s Marriage, } \\
\text { Military Service often changes in rules/policies, } \\
\text { Females should listen to Males, } \\
\text { Bias: Males are more important than females by the elder or parents, } \\
\text { Conservative before, gradually tends to change into the indication } \\
\text { of passion, infatuation or even actions to show one's own love. }\end{array}$ & $\begin{array}{l}\text { 3. The outlook, attitudes, values, moralsgoals, } \\
\text { and customs shared by a society. }\end{array}$ & Yes \\
\hline
\end{tabular}




\section{Assessment 2: Quantitative}

\subsection{The Quantitative Approach}

The five dimensions of Hofstede's cultural dimensions theory [17] [18] were used and developed into a questionnaire. The dimensions in this study with measure items are as Table 4.

Culture Dimension Questionnaires (Responses are on a five-point Likert-type scale ranging from (1) = strongly disagree to (5) = strongly agree) were collected from randomly chosen thirty senior students who all ever took elective course on "Cinema and Social Culture in Taiwan" in the senior year of the BA program. The Department Chairperson was contacted personally requesting permission to conduct the study at their institution. Eight didn't return the survey (response rate of 73.3 percent) and analyzed by SPSS. Reliability analysis using Cronbach's alpha (Scale-Reliability Analysis) was completed on five dimensions. The alphas ranged from 0.644 to 0.716 . In addition, through descriptive statistics-frequencies, mean and standard deviation were obtained as well for reference.

\subsection{Quantitative Finding}

1. The KMO value 0.694 as Table 5 revealed that the study was still suitable for proceeding with factor analysis; from Table 6, we got a high Explanation Power: 78.772\%.

Table 4. Cultural dimensions and measure item.

\begin{tabular}{|c|c|c|}
\hline Dimensions & Measure Item & Reference \\
\hline \multirow[b]{2}{*}{ 1. Power Distance } & $\begin{array}{l}\text { Q1. Cultures that endorse low power distance expect and accept power relations that are more } \\
\text { consultative or democratic. Taiwan provides employee's learning opportunity and makes } \\
\text { them progressive is high level of power distance country. }\end{array}$ & \multirow{14}{*}{$\begin{array}{l}\text { Hofstede's cultural } \\
\text { dimensions theory } \\
\text { [17] [18]: The five } \\
\text { dimensions provide } \\
\text { a standard to } \\
\text { recognize and } \\
\text { understand the } \\
\text { cultural } \\
\text { phenomenon for } \\
\text { people. }\end{array}$} \\
\hline & $\begin{array}{l}\text { Q2. The movie received significant acclaim by critics and many awards-music, photography, } \\
\text { but it was commercially unsuccessful is a case of Power Distance. }\end{array}$ & \\
\hline \multirow{3}{*}{$\begin{array}{l}\text { 2. Individualism } \\
\text { vs. Collectivism }\end{array}$} & $\begin{array}{l}\text { Q4. Taiwan is less Individualism than Collectivism that throughout people’s lifetime } \\
\text { continue to protect them in exchange for unquestioning loyalty. }\end{array}$ & \\
\hline & Q5. Taiwan males aged 18 should serve in the army. It's a Case of Collectivism. & \\
\hline & $\begin{array}{l}\text { Q6. The Actor's mother with trustworthiness \& moral Chinese traditional virtues still } \\
\text { hoped to send the ring (Family Heirloom) to the actress, even though she } \\
\text { was married to other man. It's a Case of Collectivism. }\end{array}$ & \\
\hline \multirow{3}{*}{$\begin{array}{l}\text { 3. Uncertainty } \\
\text { Avoidance }\end{array}$} & $\begin{array}{l}\text { Q7. UA is try to minimize the occurrence of unknown and unusual circumstances and } \\
\text { to proceed with careful changes step by step planning and by implementing rules, } \\
\text { laws and regulations. Taiwan was high level of UA in the past. }\end{array}$ & \\
\hline & $\begin{array}{l}\text { Q8. The techniques used by this film-natural lighting, the Director's own types, new actor/actress, } \\
\text { not filmed in studios, make audience to think about the context, different content \& cinematography, } \\
\text { less entertaining nor great story, is a Case of UA. }\end{array}$ & \\
\hline & $\begin{array}{l}\text { Q9. Ah-Yuan, less confidence and can't handle a simple job tasks well, was too scared to speak up to } \\
\text { Ah-Yun anything; at last he lost his bride. It is a Case of UA. }\end{array}$ & \\
\hline \multirow{3}{*}{$\begin{array}{l}\text { 4. Masculinity } \\
\text { vs. Femininity }\end{array}$} & $\begin{array}{l}\text { Q10. Masculinity describes that men are assertive, tough and focused on material success; whereas } \\
\text { women are more modest, tender, and concerned with the quality of life. Taiwan's MAS higher than Fem. }\end{array}$ & \\
\hline & $\begin{array}{l}\text { Q11. Elders and parents treat their sons and daughters in a different way; males are more valued } \\
\text { in Chinese traditional culture. It is a Case of MAS. }\end{array}$ & \\
\hline & $\begin{array}{l}\text { Q12. Ah-Yuan was mad about Ah-Yun's drinking alcohol with several men; females should listen } \\
\text { to males' order. It is a Case of MAS. }\end{array}$ & \\
\hline \multirow{3}{*}{$\begin{array}{l}\text { 5. Long-Term } \\
\text { Orientation } \\
\text { vs. Short-Term } \\
\text { Orientation }\end{array}$} & Q13. LTO stands for the fostering of virtues oriented toward future rewards, perseverance and thrift. & \\
\hline & $\begin{array}{l}\text { Q14. In STO societies, values promoted are related to the past and the present, including stediness, } \\
\text { respect for tradition, preservation of one’s face, reciprocation and fulfilling social obligations. }\end{array}$ & \\
\hline & $\begin{array}{l}\text { Q15. First called “Confucian dynamism”, it describes societies’ time horizon. It emphasizes the future. } \\
\text { Much of our culture is LTO. }\end{array}$ & \\
\hline
\end{tabular}


Table 5. KMO and Bartlett's test.

\begin{tabular}{|ccc}
\hline \multicolumn{2}{|c}{ Kaiser-Meyer-Olkin Measure of Sampling Adequacy. } & $\mathbf{0 . 6 9 4}$ \\
\hline Bartlett's Test of Sphericity & Approx. Chi-Square & 87.311 \\
\hline
\end{tabular}

Even though KMO is not very high enough, still it is ok to proceed the factor analysis.

Table 6. Total variance explained.

\begin{tabular}{ccc}
\hline & Rotation Sums of Squared Loadings & \\
\hline Total & \% of Variance & Cumulative \% \\
\hline 2.394 & 15.960 & 15.960 \\
2.360 & 15.736 & 31.696 \\
2.285 & 15.231 & 46.926 \\
1.813 & 12.086 & 59.012 \\
1.532 & 10.212 & 69.224 \\
1.432 & 9.547 & $\mathbf{7 8 . 7 7 2}$ \\
\hline
\end{tabular}

Extraction Method: Principal Component Analysis. (1) Explanation Power: 78.772\%; (2) Four Items \#1, 6, 10, 15 were deleted through factor analysis.

2. As Table 7 of the measure items, Q8 (The techniques used by this film-natural lighting etc. is a Case of UA) was perceived by quantitative respondents as most popularly perceived culture dimension, Q7 (Taiwan was high level of UA in the past etc.) is the next.

3. While Q4 (Taiwan is less Individualism than Collectivism that throughout people's lifetime continue to protect them in exchange for unquestioning loyalty) was considered as the least popularly perceived item. Q5 (Taiwan males aged 18 should serve in the army). It's a Case of Collectivism, ranking is second to the last.

4. Four Items \#1, 6, 10, 15 were deleted through factor analysis.

5. There was significant correlation between Taiwanese PDI and LTO/STO, as shown in Table 8.

6. From Table 8, UA also has significant correlations with IND/COL.

7. The difference between Qualitative and Quantitative Approaches is for the dimension of Long-term/ Short-term Orientation; in the qualitative, LT/ST Orientation had not been found in the film by the respondents; the others are generally the same.

8. However, we found a lot and understand more about Taiwanese culture's existence and characteristics which is deep in solid through the film. Taiwan's culture is not integrated into other culture or not becoming more alike as others, it will be impossible or a very long time for globalization to take over Taiwan's own culture.

9. Using the same methodology, the other countries can understand their cultures more.

RQ-1. What differences exist between the perceived Taiwan culture in a movie described by student-respondents and the perceived present Taiwan culture?

Nothing different. Through the above two assessments of quantitative and qualitative approaches' examination, Taiwanese culture, i.e., Ah-Yuan's mother showed trustworthiness (COL), young males lack courage (MAS) to express one's own emotion, described by the respondents, are still existing. And from the finding of the quantitative survey, except LTO/STO dimension, the other dimensions generally have same rating to the qualitative assessment:

UA $>$ LTO/STO $>$ PDI $>$ MF $>$ IND/COL (as Table 9)

Moreover, other researches ever stated Taiwanese's PDI is high. There are Qualitative 4 cases matching PDI; and the mean of PDI in this Quantitative survey is 3.9091 shown as Table 9 which is high and in consistent with the other research's premise. Therefore, we insist that there are no differences existing between the perceived Taiwan culture in a movie described by student-respondent and the perceived present Taiwan culture.

RQ-2. What is the impact of globalization on Taiwan culture? 
Table 7. Descriptive statistics.

\begin{tabular}{cccccc}
\hline & N & Minimum & Maximum & Mean & Std. Deviation \\
\hline Q8 & Statistic & Statistic & Statistic & Statistic & Statistic \\
Q7 & 22 & 3.00 & 5.00 & $\mathbf{4 . 6 8 1 8}$ & 0.56790 \\
Q9 & 22 & 2.00 & 5.00 & $\mathbf{4 . 5 0 0 0}$ & 0.80178 \\
Q14 & 22 & 2.00 & 5.00 & 4.4545 & 0.73855 \\
Q3 & 22 & 3.00 & 5.00 & 4.2273 & 0.68534 \\
Q2 & 22 & 2.00 & 5.00 & 3.9091 & 0.92113 \\
Q11 & 22 & 2.00 & 5.00 & 3.9091 & 0.81118 \\
Q13 & 22 & 2.00 & 5.00 & 3.8636 & 1.08213 \\
Q12 & 22 & 2.00 & 5.00 & 3.7273 & 0.76730 \\
Q5 & 22 & 1.00 & 5.00 & 3.4091 & 0.95912 \\
Q4 & 22 & 2.00 & 5.00 & 3.2727 & 0.82703 \\
Valid N (listwise) & 22 & 2.00 & 5.00 & 2.8636 & 0.94089 \\
\hline
\end{tabular}

Q8 has the highest mean, Q7 is the next; while Q4 has the least mean, Q5 is second to the last.

Table 8. Correlations.

\begin{tabular}{|c|c|c|c|c|c|c|}
\hline & & PDI & IndCol & UA & MF & LtoSto \\
\hline \multirow{3}{*}{ PDI } & Pearson Correlation & 1 & -0.010 & 0.131 & 0.243 & $0.515(*)$ \\
\hline & Sig. (2-tailed) & & 0.964 & 0.560 & 0.275 & 0.014 \\
\hline & $\mathrm{N}$ & 22 & 22 & 22 & 22 & 22 \\
\hline \multirow{3}{*}{ IndCol } & Pearson Correlation & -0.010 & 1 & $-0.632(* *)$ & 0.145 & -0.156 \\
\hline & Sig. (2-tailed) & 0.964 & & 0.002 & 0.519 & 0.487 \\
\hline & $\mathrm{N}$ & 22 & 22 & 22 & 22 & 22 \\
\hline \multirow{3}{*}{ UA } & Pearson Correlation & 0.131 & $-0.632(* *)$ & 1 & -.275 & 0.188 \\
\hline & Sig. (2-tailed) & 0.560 & 0.002 & & .215 & 0.402 \\
\hline & $\mathrm{N}$ & 22 & 22 & 22 & 22 & 22 \\
\hline \multirow{3}{*}{ MF } & Pearson Correlation & .243 & -.145 & -0.275 & 1 & -0.124 \\
\hline & Sig. (2-tailed) & .275 & 0.519 & 0.215 & & 0.583 \\
\hline & $\mathrm{N}$ & 22 & 22 & 22 & 22 & 22 \\
\hline \multirow{3}{*}{ LtoSto } & Pearson Correlation & $0.515(*)$ & -0.156 & 0.188 & -0.124 & 1 \\
\hline & Sig. (2-tailed) & 0.014 & 0.487 & 0.402 & 0.583 & \\
\hline & $\mathrm{N}$ & 22 & 22 & 22 & 22 & 22 \\
\hline
\end{tabular}

*Correlation is significant at the 0.05 level (2-tailed); **Correlation is significant at the 0.01 level (2-tailed). (1) PDI has significant correlations with LTO/STO; (2) IndCol has significant correlations with UA. 
Table 9. Descriptive statistics by category.

\begin{tabular}{cccccc}
\hline & $\mathrm{N}$ & Minimum & Maximum & Mean & Std. Deviation \\
\hline UA & 22 & 2.67 & 5.00 & $\mathbf{4 . 5 4 5 5}$ & 0.47749 \\
LtoSto & 22 & 3.00 & 5.00 & 3.9773 & 0.58711 \\
PDI & 22 & 2.50 & 5.00 & 3.9091 & 0.70096 \\
MF & 22 & 2.00 & 4.50 & 3.6364 & 0.77432 \\
IndCol & 22 & 2.00 & 5.00 & $\mathbf{3 . 0 6 8 2}$ & 0.76057 \\
Valid N (listwise) & 22 & & & \\
\hline
\end{tabular}

By category, UA is the highest dimension; IndCol is the lowest dimension.

Nothing. In the qualitative finding the above, all of the behaviors described from the beginning to the end in the film by respondents were almost related to Hofstede's culture dimensions without any exception. Furthermore, the film earned awards of three international and one Taiwan domestic on edit, music, director, photography in so many years ago; it must have something special or features from other countries, and that is the culture, Taiwan culture. It is no wonder, the older, the new generation of viewers praise it (even if there was tiny different points of view for this film); however, the film with Taiwan culture even attracts the foreigners (e.g., France, Portugal) viewers to like it. And which represents Taiwanese culture's existence and characteristics through the movie. That is, Taiwan's culture is not integrated into other culture or is not becoming more alike, globalization is not changing or impacting Taiwan culture so fast. Neither do the other countries.

RQ-3. How does globalization changes culture and affect global marketing strategies?

Not yet. Results show that substantive differences even among each behavior or value of our life; consequently, the issue of "different cultures becoming more alike" will not be coming so fast as mentioned the above. Whatever, the best global marketing strategies no matter how if globalization comes and changes our culture or not, the answer still is respect, accept, involve other's culture as well as the following:

In Hofstede's theory; lower Power Distance except and accept power relations that are more consultative or democratic.

In MAS/FIN; men and women have the same values emphasizing modesty and caring even though men and women are significantly different.

As LTO/STO promotes-Respect for tradition (and other culture), preservation of one's face, reciprocation and fulfilling social obligation, are the tools of the best global marketing strategies.

\section{Original Contributions and Practical Implications}

The research has original contributions for linking and developing marketing strategy to cultural values of movie viewers, as well as implications for linking to cultural values of sightseeing visitors. Both quantitative and qualitative approaches were used by this study to analyze the movie's perception or abstract entities etc., as culture has been essential to success in marketing, so the provided information of this study is not too general due to the follows:

a) Most qualitative research is not taking quantitative research together, but this paper does;

b) The paper uses Movie-greater information sources and part of popular culture to explore if the globalization is changing culture;

c) The theories used by this study are Hofstede's cultural dimensions theory and Dunning' theory about globalization, the two are important world-famous theories, rarely to be used together.

d) There are three research questions in p. 3. and their answers are in pp. 21-22 (Quantitative Finding in p. 21), and the difference between qualitative and quantitative approaches is for one valuable different (the dimension of Long-term/Short-term Orientation) only; the others are generally the same; therefore, the results of this study are reasonable and reliable.

e) The paper started statement from the qualitative method and then proved by quantitative (assessments), the both nearly have the same result with scientific analysis and inference.

This study provides the followings: 
1. Better understand the effect of expanding culture on movie or else;

2. Assist global marketers in developing a greater understanding of the relation of culture and globalization;

3. Contribute unique research results to the academic and professional study of the behaviour or perception of movie viewers/consumers. In summary, this

(1) Expand scope of theoretical knowledge.

(2) Add empirical data to support the theory.

(3) Provide effective tools for movie producers, relative enterprises, to apply the results, dimension, in the competitive environment.

(4) For assessment purpose, ASSESSMENT 1: QUALITATIVE was executed in pp. 17-18; from the assessment by qualitative itself, if the study did not use quantitative, would still be enough to verify the reliability of this study.

(5) There are no differences existing between the perceived Taiwan culture in a movie described by student-respondent and the perceived present Taiwan culture (RQ1).

(6) Taiwan's culture is not integrated into other culture or is not becoming more alike, globalization is not changing or impacting Taiwan culture so fast. Neither do the other countries (RQ2).

(7) Results show that substantive differences even among each behavior or value of our life; consequently, the issue of “different cultures becoming more alike” will not be coming so fast as mentioned the above (RQ3).

\section{Conclusions and Recommendations}

We conclude by delineating/depicting future that researches on culture that affects global marketing strategies should consider developing a more comprehensive understanding of the relationships between other resources (TV/drama) and cultures, and value creation. However, notwithstanding many examples of the fusion of cultures can be found around the world, or in spite of that cultural change is an inevitable art of national evolution, or cultures take what they want from other cultures and others, if the category of human-being exists as well as from the above in terms of marketing in Taiwan, we could say that it is difficult for different cultures to be becoming more alike in short time/or recently.

Since 1989, the world has seen the proliferation of ethnic conflict, the rise of militant Islam, the intensification of group hatred and nationalism, massacres, and two genocides unprecedented since the Nazi Holocaust [22] (p. 123). Gannon [23] stated that a more basic reason for culture research is that our globalized world demand cross-cultural expertise if we are to survive.

Therefore, even though cultures are becoming more alike, the key to such situation affecting global marketing strategies is to encourage governments to play a vital role involving in identifying and understanding each other's culture and cultural factors which affect consumer decision making. Cultural and symbolic resources in strategy research were usually neglected role; while many studies have shown how the both are needed and create value [9]. Thus, there will have been possibilities for maximizing the marketing in global business competition, while minimizing its negative social, environmental or cultural impacts. If Hofstede's approach is valid, then Culture's Consequences will continue to inform, inspire, and guide human or customer to have lifetime value and achieve a sustainable competitive advantage.

\section{References}

[1] Li, L. (2013) Screen-Induced Tourism: Perceived Destination Image and Intention to Visit. Tourism Tribune/Lvyou Xuekan, 28, 61-72.

[2] Lee, S. and Ko, E. (2013) Cinderella Storytelling in 21st Century: Interpreting Popular Culture in the Movies via Visual Narrative Arts. In: Ko, E. and Woodside, A.G., Eds., Luxury Fashion and Culture (Advances in Culture, Tourism and Hospitality Research, 7), Emerald Group Publishing Limited, Bingley, 91-99.

[3] Dalpiaz, E., Rindova, V.P. and Ravasi, D. (2010) Where Strategy Meets Culture: The Neglected Role of Cultural and Symbolic Resources in Strategy Research. In: Baum, J.A.C. and Lampel, J., Eds., The Globalization of Strategy Research (Advances in Strategic Management, 27), Emerald Group Publishing Limited, Bingley, 175-208. http://dx.doi.org/10.1108/S0742-3322(2010)0000027010

[4] Marx, K. and Engels, F. (1848) The Communist Manifesto (1848). http://public.wsu.edu/ brians/world_civ/worldcivreader/world_civ_reader_2/marx.html

[5] Dunning, J.H. (2006) Towards a New Paradigm of Development: Implications for the Determinants of International 
Business. Transnational Corporations, 15, 173-227. http://unctad.org/en/docs/iteiit20061a7_en.pdf

[6] Sun, J.X. and Wang, X.R. (2012) The "Nothing” and "Something” during the Cultural Changes in Lijiang Ancient Town: A Case Study of Lijiang Ancient Town's Bars. Tourism Tribune/Lvyou Xuekan, 27, 73-83.

[7] Henderson, J.C. (2013) Ethnic Cultures, Globalization, and Tourism: Eurasians in Singapore. Tourism Culture \& Communication, 13, 67-77.

[8] Yahoo (2006) What Is a Simple Definition of Culture? https://answers.yahoo.com/question/index?qid=20061201021425AAaGcz9

[9] Wikipedia, the Free Encyclopedia (2014) Culture-Simple. National Cultures-Regional or Non-Regional Cultures.

[10] Measuring Cultural Participation (2009) United States Country Attend a Music Festival or go to the Cinema (Philadelphia Cultural Engagement Index). In: UNESCO Framework for Cultural Statistics Handbook No. 2, UNESCO Institute for Statistics, Canada, 1-132. http://www.uis.unesco.org/culture/Documents/fcs-handbook-2-cultural-participation-en.pdf

[11] Pandey, S. (2012) Using Popular Movies in Teaching Cross-Cultural Management. European Journal of Training and Development, 36, 329-350. http://dx.doi.org/10.1108/03090591211204779

[12] Parker, B. (2005) Globalization of Culture. Introduction to Globalization and Business, California: Sage Publications, 1-188. http://books.google.com.tw/books?id=nCtQxZBZl3QC\&pg=PA187\&lpg=PA187\&dq=Culture

[13] Yang, L.Y. (2005) Lighting the Way to the Future: The TFT-LCD Industry. Seeing the World's Cultural Heritage in Taiwan Sino: Art and Culture-Taiwanese Culture. 64. http://www.sinorama.com.tw/en/show_issue

[14] Mallinger, M., Goowin, D. and O’hara, T. (2009) Recognizing Organizational Culture in Managing Change. Graziadio Business Review, 12. http://gbr.pepperdine.edu/2010/08/recognizing-organizational-culture-in-managing-change/

[15] Geertz, C. (2007) “Ideology as a Cultural System”. Scanned, Edited and Tagged by: Courtney Danforth-9/27/96. http://www.gongfa.com/geertz1.htm

[16] Merriam-Webster Online (2014) Ideology-Definitions of Ideology. Ideology Is a Key Term in Literary, Cultural, and Film Studies. http://www.merriam-webster.com/dictionary/ideology https://faculty.washington.edu/mlg/courses/definitions/Ideology.html

[17] Hofstede, G. (1980) Dimensions of National Cultures. Wikipedia, the Free Encyclopedia (2014) Hofstede’s Cultural Dimensions Theory. http://www.geerthofstede.nl/dimensions-of-national-cultures

[18] Hofstede, G. (2001) Culture’s Consequences: Comparing Values, Behaviors, Institutions and Organizations across Nations.

http://www.amazon.com/Cultures-Consequences-Comparing-Institutions-Organizations/dp/0803973241/ref=sr_1_2?s= books\&ie=UTF8\&qid $=1413727384 \& s r=1-2$

[19] Keaney, D. (2008) Among Such Tools Are: Expert Interviews/in Depth Interviews; Focus Groups; Observation; Case Studies. http://www.nsf.gov/pubs/1997/nsf97153/chap_3.htm

[20] Wikipedia, the Free Encyclopedia Dust in the Wind (Film). http://en.wikipedia.org/wiki/Dust_in_the_Wind_(film)

[21] Hofstede, G., Hofstede, G.J. and Minkov, M. (2010) Cultures and Organizations: Software of the Mind. Revised and Expanded, 3rd Edition, McGraw-Hill, New York, 1-550.

[22] Chua, A. (2003) World on Fire. Doubleday, New York.

[23] Gannon, M.J. (2004) Global Cultures. 3rd Edition, Sage Publications, Thousand Oaks, London. 


\section{Appendix}

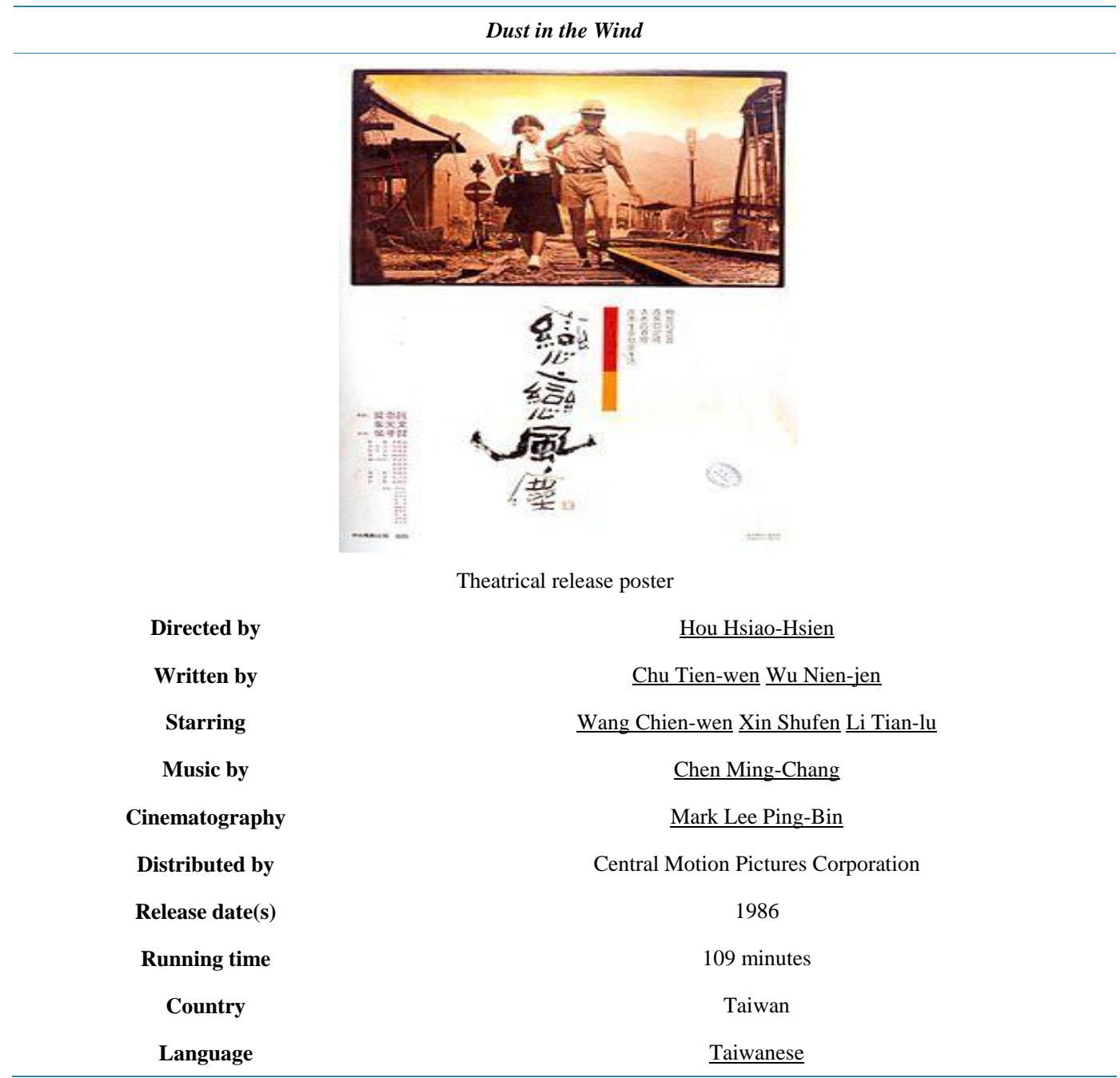

Figure A1. Dust in the wind. 
Scientific Research Publishing (SCIRP) is one of the largest Open Access journal publishers. It is currently publishing more than 200 open access, online, peer-reviewed journals covering a wide range of academic disciplines. SCIRP serves the worldwide academic communities and contributes to the progress and application of science with its publication.

Other selected journals from SCIRP are listed as below. Submit your manuscript to us via either submit@scirp.org or Online Submission Portal.
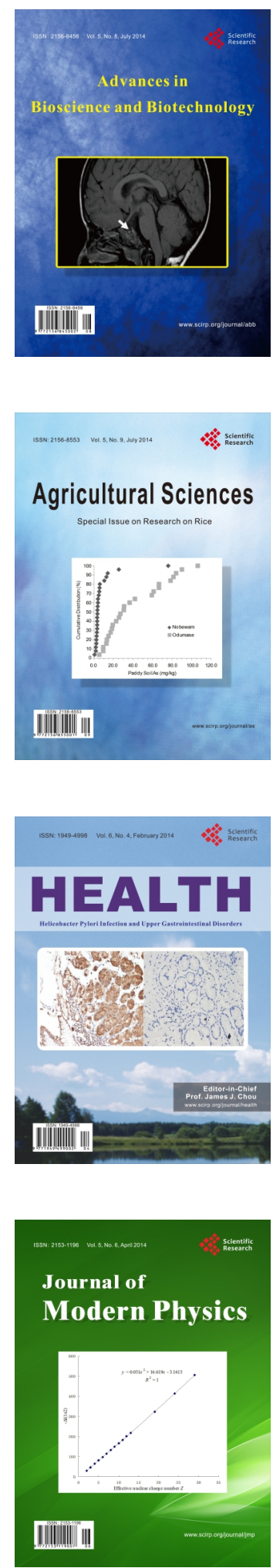
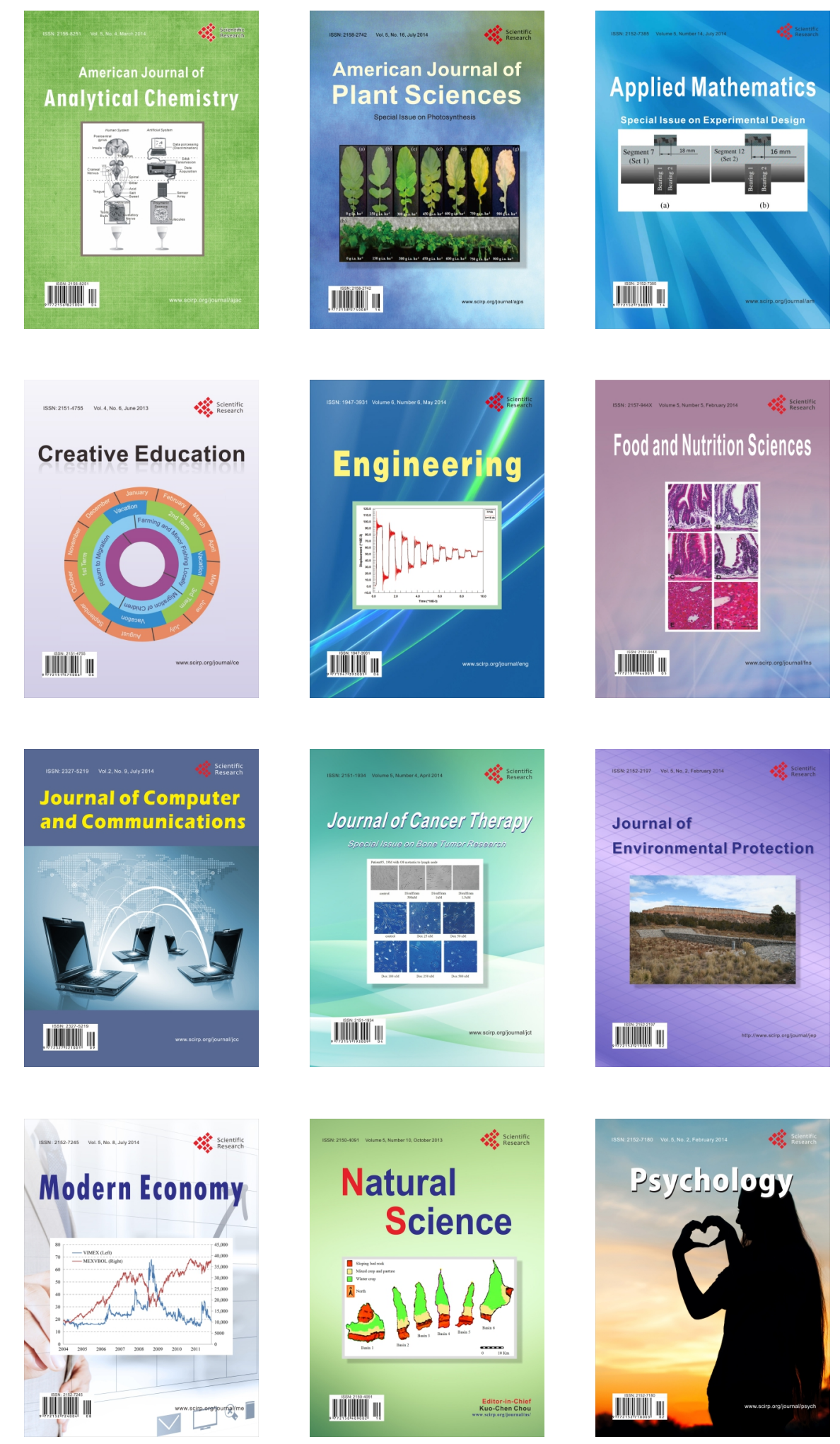